\title{
Flexible synthetic routes to poison-frog alkaloids of the 5,8-disubstituted indolizidine-class I: synthesis of common lactam chiral building blocks and application to the synthesis of (-)-203A, (-)-205A, and $(-)-219 \mathrm{~F}$
}

\author{
Naoki Toyooka*1, Dejun Zhou ${ }^{1}$, Hideo Nemoto ${ }^{1}$, H. Martin Garraffo ${ }^{2}$, \\ Thomas F. Spande ${ }^{2}$ and John W. Daly ${ }^{2}$
}

\section{Full Research Paper}

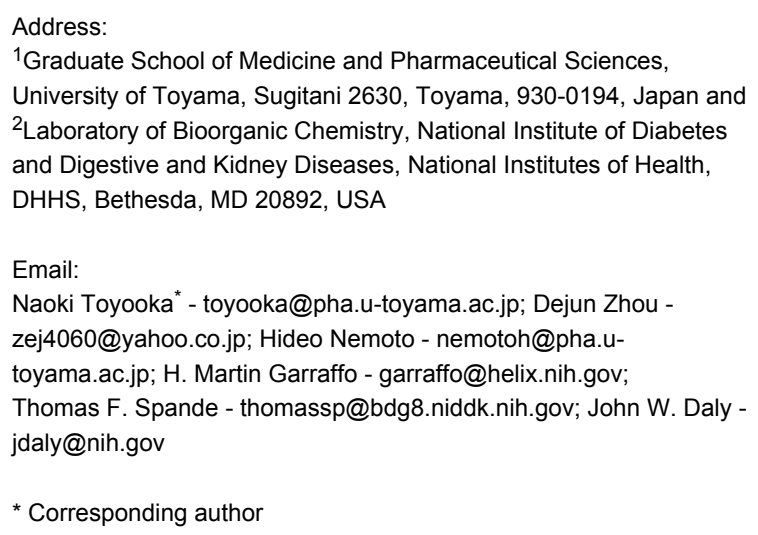

${ }^{1}$ Graduate School of Medicine and Pharmaceutical Sciences, University of Toyama, Sugitani 2630, Toyama, 930-0194, Japan and

${ }^{2}$ Laboratory of Bioorganic Chemistry, National Institute of Diabetes and Digestive and Kidney Diseases, National Institutes of Health, DHHS, Bethesda, MD 20892, USA

Email:

Naoki Toyooka* - toyooka@pha.u-toyama.ac.jp; Dejun Zhou zej4060@yahoo.co.jp; Hideo Nemoto - nemotoh@pha.utoyama.ac.jp; H. Martin Garraffo - garraffo@helix.nih.gov;

Thomas F. Spande - thomassp@bdg8.niddk.nih.gov; John W. Daly -

jdaly@nih.gov

* Corresponding author

Beilstein Journal of Organic Chemistry 2007, 3, No. 29 doi:10.1186/1860-5397-3-29

Received: 19 July 2007

Accepted: 28 September 2007

Published: 28 September 2007

(C) 2007 Toyooka et al; licensee Beilstein-Institut

License and terms: see end of document.

\section{Abstract \\ Background}

The 5,8-disubstituted indolizidines are the largest class of poison-frog alkaloids found in anuran skin, and are of considerable interest because of their inhibitory effects on the neuronal nicotinic acetylcholine receptors. Many synthetic strategies for the construction of this nucleus have been reported: however, a flexible route has not been reported to date.

\section{Results}

Synthesis of lactam chiral building blocks for the flexible synthesis of the title alkaloids has been achieved using a Michael-type conjugate addition reaction to a chiral cyclic enamine ester as the key step in constructing the trisubstituted piperidine ring system. To demonstrate the usefulness of these chiral building blocks, syntheses of (-)-203A, (-)-205A from 1, and (-)-219F from 2 have been achieved.

\section{Conclusion}

The total synthesis of (-)-203A, (-)-205A, and (-)-219F was achieved, and the absolute stereochemistry of natural 203A was determined to be $5 S, 8 R, 9 S$. In addition, the relative stereochemistry of natural $\mathbf{2 1 9 F}$ was determined. 


\section{Introduction}

The indolizidine ring system has been widely found in microbial, plant, and animal sources, and many natural products containing this ring system show interesting biological activities. [1] The skin extracts of poison-frogs are a rich source of indolizidines. [2] There are about 20 examples of 3,5-disubstituted indolizidines and about 80 of the 5,8-disubstituted indolizidines. Furthermore, many of such poison-frog alkaloids show significant activities, for example with nicotinic acetylcholine receptors (nAChRs) of the central nervous system. [3] Our syntheses and then biological evaluations of poison-frog alkaloids, [4-10] revealed that the 5,8-disubstituted indolizidine (-)-
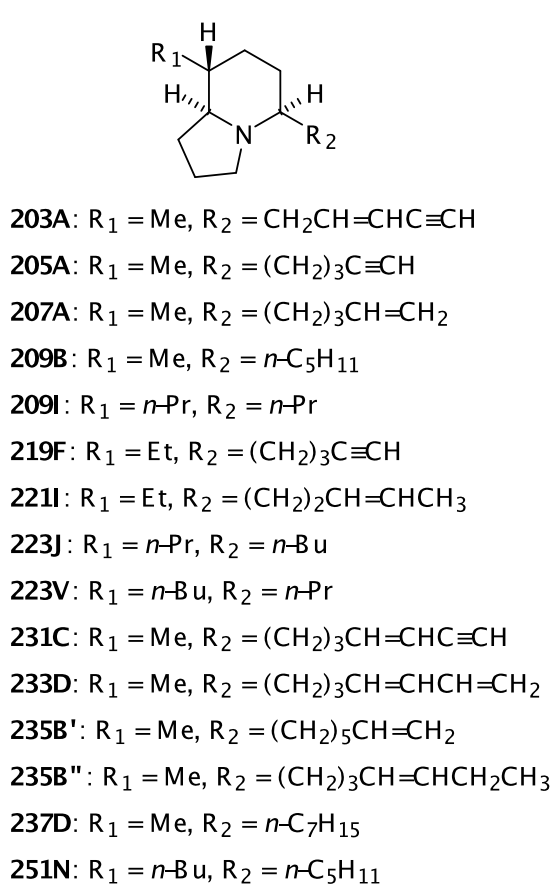

Figure 1: Representative examples of 5,8-Disubstituted Indolizidines.
235B', exhibited selective and potent blockade of $\alpha 4 \beta 2$ nAChRs. [11] Alkaloids of this class with various substituents at the 5-and 8-positions that have been synthesized are shown in Figure 1. All side-chain double bonds in these synthetic compounds have the cis $(Z)$ configuration. Our flexible synthetic strategy provides a powerful tool for the synthesis of 5,8-disubstituted indolizidines, permitting detailed investigation of structure activity relationships for blockade of nAChRs by this class of alkaloids.

In this contribution, we describe the synthesis of the common lactam chiral building blocks that permit the flexible synthesis of 5,8-disubstituted indolizidines. Their application to the synthesis of (-)-203A, (-)-205A, and (-)-219F illustrates in detail the synthetic procedures employed. [12]

\section{Results and Discussion}

To realize the versatile synthesis of the 5,8-disubstituted indolizidine class of poison-frog alkaloids, we designed two lactam chiral building blocks $(\mathbf{1}, \mathbf{2})$. The substituent at the 8-position is stereoselectively created by our original Michael-type conjugate addition reaction. [13,14] Various substituents at the 5-position would be introduced using the protected hydroxymethyl sidechain (Figure 2).

The synthesis began with the known piperidone 3, [15] which was treated with $n$-BuLi and then $\mathrm{CbzCl}$ to provide the $\mathrm{Cbz}-$ urethane 4. Treatment of $\mathbf{4}$ with LiHMDS followed by $2-[\mathrm{N}, \mathrm{N}-$ bis(trifluoromethylsulfonyl)amino]-5-chloropyridine (Comins' reagent) [16] gave the enoltriflate 5 in good yield. The palladium-catalyzed carbon monoxide insertion reaction [17] in the presence of $\mathrm{MeOH}$ afforded the enaminoester 6. The key Michael-type conjugate addition reaction of $\mathbf{6}$ with lithium dimethylcuprate or divinylcuprate proceeded smoothly to

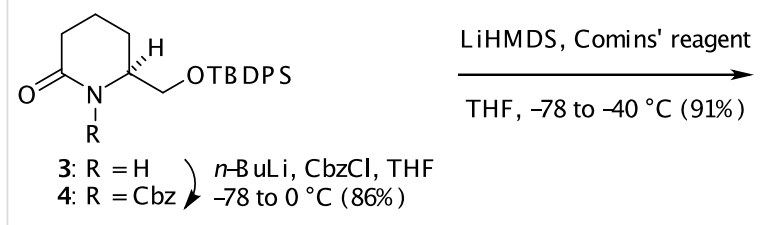

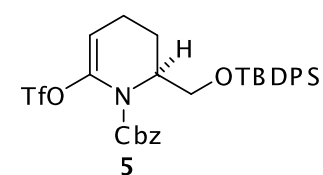

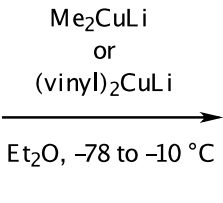

$\mathrm{Pd}\left(\mathrm{Ph}_{3} \mathrm{P}\right)_{4}, \mathrm{CO}, \mathrm{MeOH}, \mathrm{Et}_{3} \mathrm{~N}$

$\mathrm{DMF}, 75^{\circ} \mathrm{C}(78 \%)$<smiles>CC(=O)OCC1CCC=C(C(C)=O)N1C(=O)OCc1ccccc1</smiles>

Scheme 1: Construction of tri-substituted piperidine ring systems $(\mathbf{7}, \mathbf{8})$. 


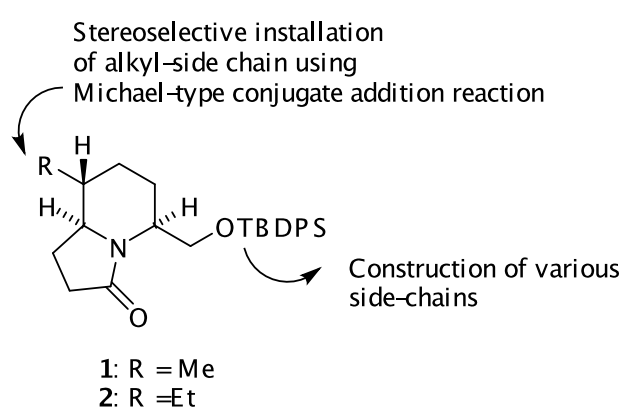

Figure 2: Synthetic Strategies to 5,8-Disubstituted Indolizidines from Chiral Building Blocks $(\mathbf{1 , 2})$.

provide the trisubstituted piperidines $(7,8)$ as single stereoisomers in excellent yields.

The stereochemical course of the above addition reaction can be rationalized as follows: The enamine ester $\mathbf{6}$ would adopt conformation A owing to $\mathrm{A}^{(1,3)}$ strain [18] between the benzyloxycarbonyl group on nitrogen and the substituent at the $\alpha$-position, The methyl or vinyl anion then attacks from the $\alpha$-orientation controlled by a stereoelectronic effect [19] producing the desired trisubstituted piperidine as a single isomer. This argument can also be explained by the Cieplak's hypothesis [20] as shown in Figure 3. Reduction of the ester moiety in $\mathbf{7}$ and $\mathbf{8}$ with Super-Hydride gave the corresponding alcohols $(\mathbf{9}, \mathbf{1 0})$ in good yield. Swern oxidation of $\mathbf{9}$ or $\mathbf{1 0}$ followed by HornerEmmons reaction of the resulting aldehydes afforded the $\alpha, \beta$ -

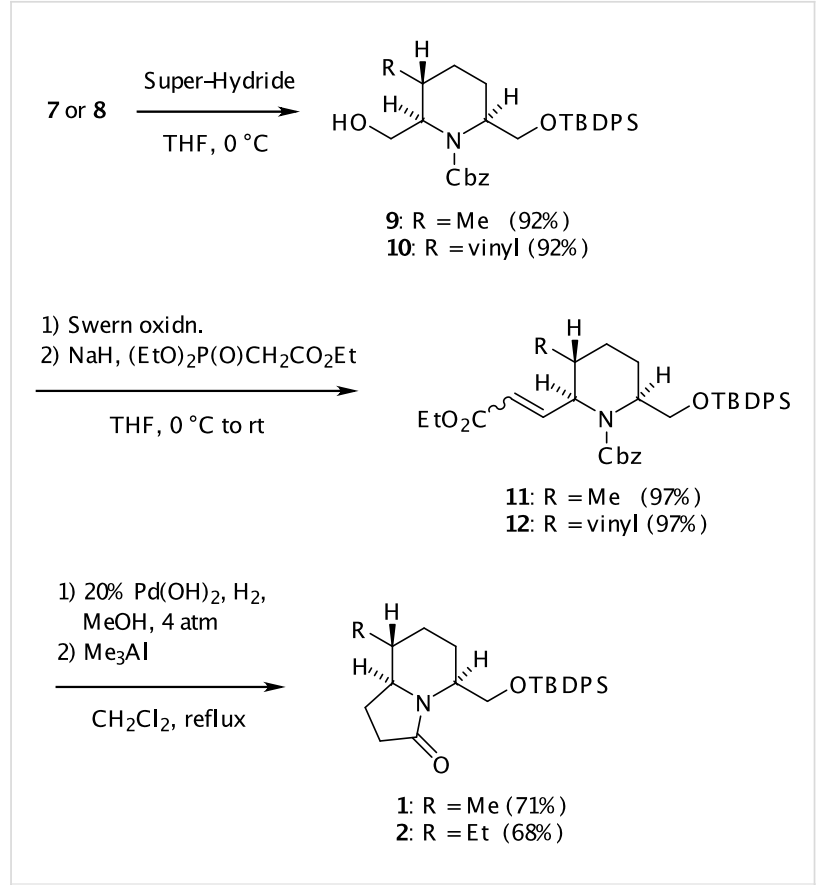

Scheme 2: Synthesis of common lactam-type chiral building blocks (1, 2).

unsaturated esters $(\mathbf{1 1}, \mathbf{1 2})$ each in $97 \%$ yield. Hydrogenation of the double bond in $\mathbf{1 1}$ or $\mathbf{1 2}$ over $20 \% \mathrm{Pd}(\mathrm{OH})_{2}$ and then treatment of the resulting deblocked amino alcohols with trimethylaluminum under Weinreb's conditions [21] gave rise to the lactams 1 and $\mathbf{2}$ in $71 \%$ and $68 \%$ overall yields, respectively.

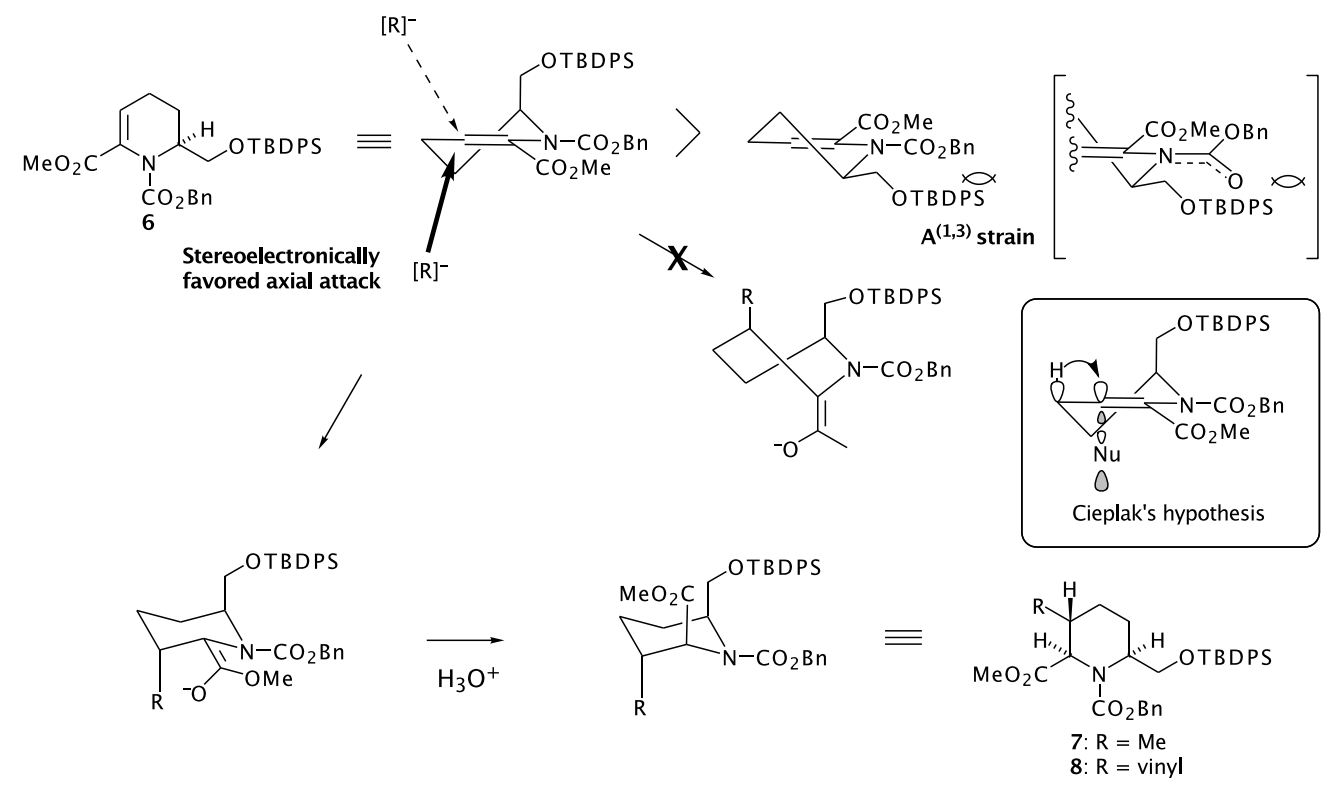

Figure 3: Stereochemical Course of Key Michael-type Conjugate Addition Reaction of 6. 


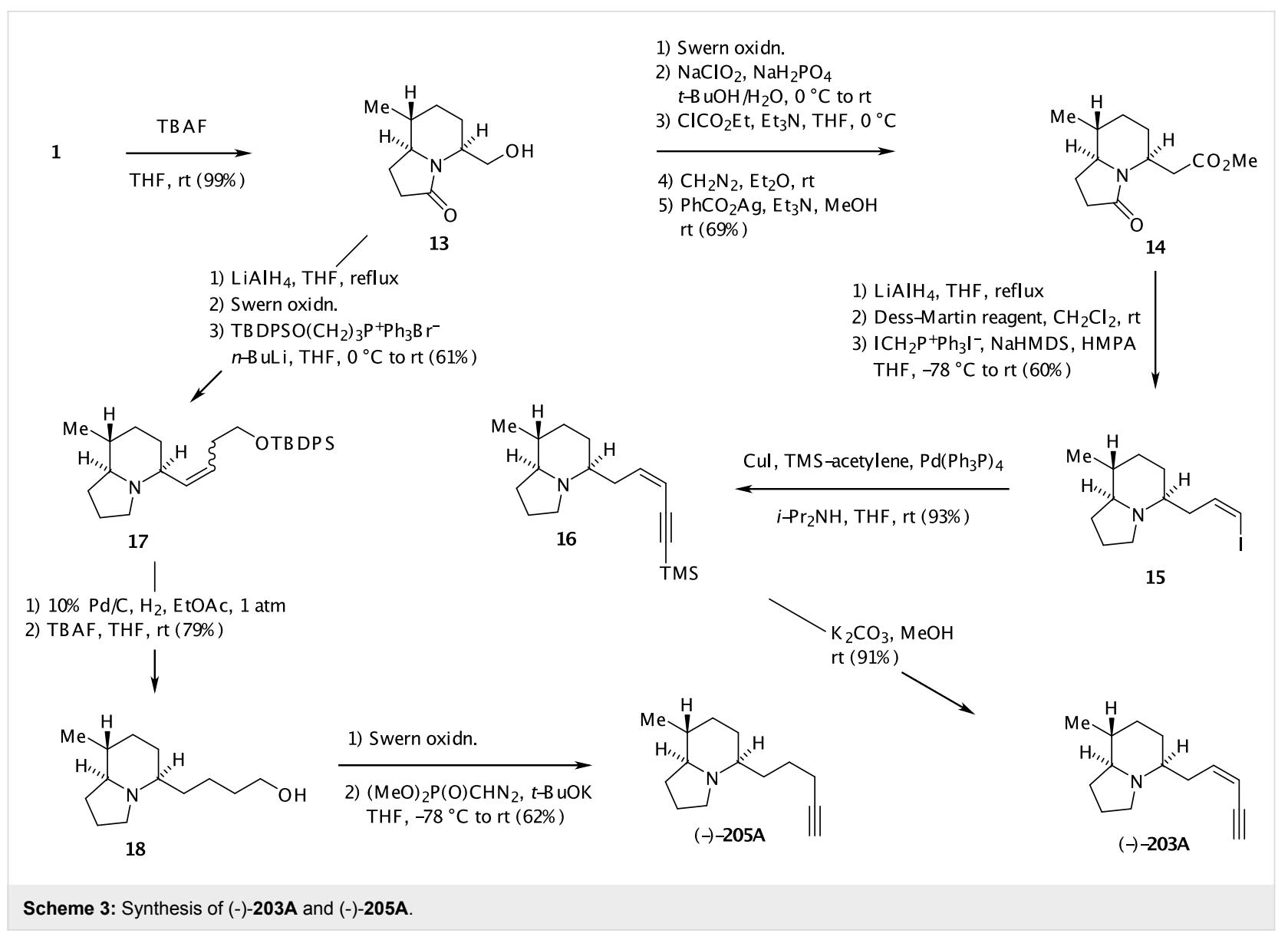

To demonstrate the utility of the chiral lactam building blocks, we conducted the total synthesis of indolizidines (-)-203A [22] and (-)-205A [23] from 1, and (-)-219F [2] from 2, respectively (Scheme 3, Scheme 4). Removal of the silyl protecting group in 1 was performed by treatment with TBAF to afford the corresponding alcohol 13, which was converted to the homologated ester 14 via a two-step oxidation, followed by an Arndt-Eistert sequence of the resulting carboxylic acid. Reduction of both carbonyl groups in $\mathbf{1 4}$ with lithium aluminum hydride provided the alcohol, which was directly used for formation of Z-iodoolefin 15. Thus, the Dess-Martin periodinane oxidation [24] of the alcohol, followed by Wittig reaction of the resulting aldehyde under Stork's reaction conditions, [25] gave the olefin. Purification by silica gel column chromatography afforded pure $\mathbf{1 5}$ in $60 \%$ isolated yield. The coupling reaction of 15 with TMS-acetylene under Sonogashira's conditions [26] gave rise to the product 16. Finally, treatment of $\mathbf{1 6}$ with $\mathrm{K}_{2} \mathrm{CO}_{3}$ in $\mathrm{MeOH}$ provided (-)-203A. The GC-MS and GC-FTIR spectra of synthetic (-)-203A were identical with those of the natural product, and comparison of the optical rotation of the synthetic material $\left([\alpha]_{\mathrm{D}}{ }^{26}-94.5\left(\mathrm{c} 2.0, \mathrm{CHCl}_{3}\right)\right.$ with the natural product, lit. $\left.[22][\alpha]_{\mathrm{D}}-23.3\left(\mathrm{c} 0.3, \mathrm{CHCl}_{3}\right)\right)$ suggest that the absolute stereochemistry of natural $\mathbf{2 0 3 \mathbf { A }}$ is $5 S, 8 R, 9 S$.
We achieved the total synthesis of (-)-205A starting from 1 via 13 (Scheme 3). Lithium aluminum hydride reduction of $\mathbf{1 3}$ followed by Swern oxidation and Wittig reaction of the resulting aldehyde gave the olefin 17. Hydrogenation of $\mathbf{1 7}$ over $\mathrm{Pd} / \mathrm{C}$, and treatment of the resulting indolizidine with TBAF provided the homologated alcohol 18. Finally, the terminal triple bond was constructed by Seyferth-Gilbert reaction. [27] After oxidation of $\mathbf{1 8}$ under the Swern conditions, treatment of the resulting aldehyde with Seyferth-Gilbert reagent in the presence of $t$-BuOK furnished (-)-205A, whose spectral data were identical with reported values. [22,28]

In addition, (-)-219F, a 5,8-disubstituted indolizidine with an ethyl group at C-8, [2] was synthesized from 2 (Scheme 4). The lactam 2 was converted to the homologated alcohol 20 via 19 as used with 1 in the synthesis of (-)-205A, which was then transformed into (-)-219F using the Seyferth-Gilbert reaction after Swern oxidation of $\mathbf{2 0 .}$

Although the direct comparison of the NMR spectra of the synthetic alkaloid with the natural product was not possible due to the scarcity of natural product, the GC-MS and GC-FTIR spectra of the synthetic material were identical with those of 


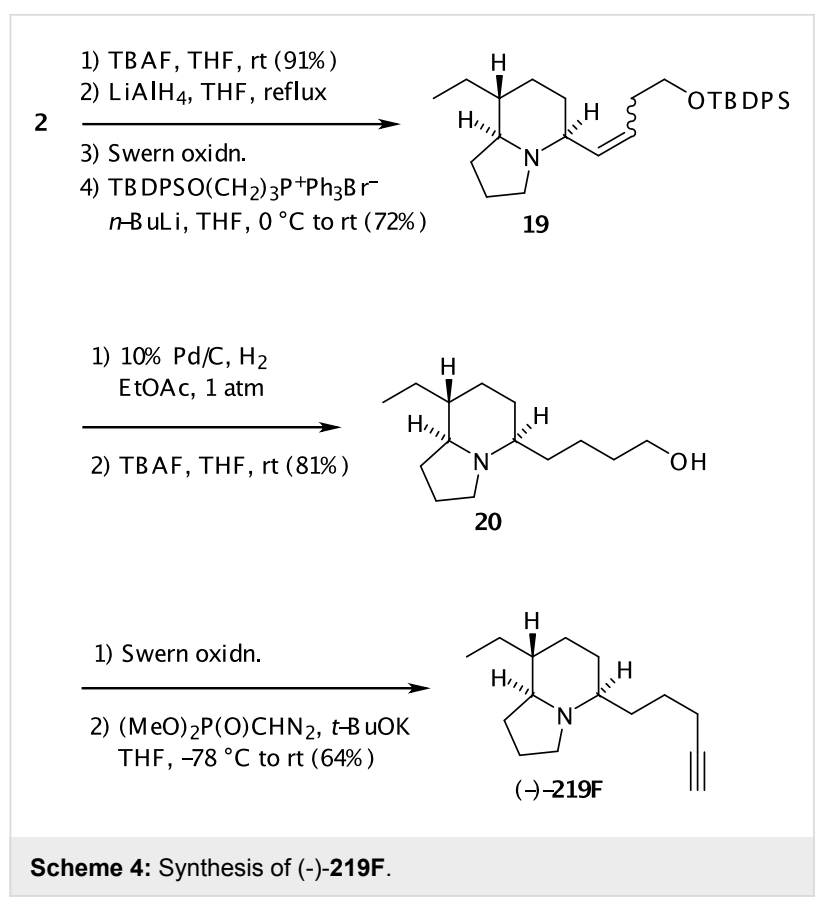

natural product detected in the Madagascan mantellid frog, Mantella betsileo. Thus, the relative stereochemistry of natural 219F was established.

In conclusion, we succeeded in the construction of chiral lactam building blocks $(\mathbf{1}, \mathbf{2})$ for the synthesis of three representative poison-frog alkaloids of the 5,8-disubstituted indolizidine class; these were alkaloids (-)-203A, (-)-205A, and (-)-219F (experimental details can be found in Supporting Information File 1). This flexible synthetic route starting from $\mathbf{1}$ or $\mathbf{2}$ will be amenable to any side-chain at the 5-position of these alkaloids. Such indolizidines are expected to show inhibitory effects on the nAChRs, and the biological results will be reported in due course.

\section{Supporting Information}

\section{Supporting Information File 1}

Experimental details for the synthesis of (-)-203A, (-)-

205A, and (-)-219F. Experimental data which includes experimental details on the spectral instruments, elemental analyzer.

[http://www.beilstein-journals.org/bjoc/content/ supplementary/1860-5397-3-29-S1.doc]

\section{Acknowledgments}

This work was supported in part by a grant-in-aid for Scientific Research (C, No. 17590004) by the Japan Society for the Promotion of Science (JSPS). Work at NIH was supported by the intramural research program of NIDDK.

\section{References}

1. Michael, J. P. Nat. Prod. Rep. 2007, 24, 191-222. doi:10.1039/ b509525p

2. Daly, J. W.; Spande, T. F.; Garraffo, H. M. J. Nat. Prod. 2005, 68, 1556-1575. doi:10.1021/np0580560

3. Daly, J. W. Cell. Mol. Neurobiol. 2005, 25, 513-552. doi:10.1007/ s10571-005-3968-4

4. Toyooka, N.; Nemoto, H.; Garraffo, H. M.; Spande, T. F.; Daly, J. W. Tetrahedron 2005, 61, 1187-1198. doi:10.1016/j.tet.2004.11.060

5. Toyooka, N.; Kawasaki, M.; Nemoto, H.; Garraffo, H. M.; Spande, T. F.; Daly, J. W. Heterocycles 2005, 65, 5-8.

6. Toyooka, N.; Tsuneki, H.; Kobayashi, S.; Zhou, D.; Kawasaki, M.; Kimura, I.; Sasaoka, T.; Nemoto, H. Curr. Chem. Biol. 2007, 1, 97-114.

7. Toyooka, N.; Tsuneki, H.; Nemoto, H. Yuki Gosei Kagaku Kyokaishi 2006, 64, 49-60.

8. Toyooka, N.; Nemoto, H. In New Methods for the Asymmetric Synthesis of Nitrogen Heterocycles; Vicario, J. L.; Badía, D.; Carrillo, L., Eds.; Trivandrum, Kerala, India: Research Signpost, 2005; pp 149-163.

9. Toyooka, N.; Nemoto, H. In Recent Research Developments in Organic Chemistry; Pandalai, S. G., Ed.; Trivandrum, Kerala, India: TRANSWORLD RESEARCH NETWORK, 2002; Vol. 6, pp 611-624.

10. Tsuneki, H.; You, Y.; Toyooka, N.; Kagawa, S.; Kobayashi, S.; Sasaoka, T.; Nemoto, H.; Kimura, I.; Dani, J. A. Mol. Pharmacol. 2004, 66, 1061-1069. doi:10.1124/mol.104.000729

11. Toyooka, N.; Zhou, D.; Nemoto, H.; Garraffo, H. M.; Spande, T. F.; Daly, J. W. Tetrahedron Lett. 2006, 47, 577-580. doi:10.1016/ j.tetlet.2005.11.047

12. Toyooka, N.; Zhou, D.; Nemoto, H.; Garraffo, H. M.; Spande, T. F.; Daly, J. W. Tetrahedron Lett. 2006, 47, 581-582. doi:10.1016/ j.tetlet.2005.11.046

13. Momose, T.; Toyooka, N. J. Org. Chem. 1994, 59, 943-945. doi:10.1021/jo00084a004

14. Toyooka, N.; Tanaka, K.; Momose, T.; Daly, J. W.; Garraffo, H. M. Tetrahedron 1997, 53, 9553-9574. doi:10.1016/S0040-4020(97)006418

15. Hodgkinson, T. J.; Shipman, M. Synthesis 1998, 1141-1144. doi:10.1055/s-1998-2123

16. Comins, D. L.; Dehghani, A. Tetrahedron Lett. 1992, 33, 6299-6302. doi:10.1016/S0040-4039(00)60957-7

17. Cacchi, S.; Morera, E.; Orter, G. Tetrahedron Lett. 1985, 26 , 1109-1112. doi:10.1016/S0040-4039(00)98525-3

18. Hoffmann, R. W. Chem. Rev. 1989, 89, 1841-1873. doi:10.1021/ cr00098a009

19. Deslongchamps, P. Stereoelectronic Effects in Organic Chemistry; New York: Pergamon, 1983.; pp 209-290

20. Cieplak, A. S. J. Am. Chem. Soc. 1981, 103, 4540-4552. doi:10.1021/ ja00405a041

21. Basha, A.; Lipton, M.; Weinreb, S. M. Tetrahedron Lett. 1977, 4171-4174. doi:10.1016/S0040-4039(01)83457-2

22. Tokuyama, T.; Tsujita, T.; Shimada, A.; Garraffo, H. M.; Spande, T. F.; Daly, J. W. Tetrahedron 1991, 29, 5401-5414. doi:10.1016/S00404020(01)80974-1

23. Tokuyama, T.; Nishimori, N.; Shimada, A.; Edwards, M. W.; Daly, J. W. Tetrahedron 1987, 43, 643-652. doi:10.1016/S0040-4020(01)89998-1

24. Dess, D. B.; Martin, J. J. Org. Chem. 1983, 48, 4155-4156. doi:10.1021/jo00170a070 
25. Stork, G.; Zhao, K. Tetrahedron Lett. 1989, 30, 2173-2174. doi:10.1016/S0040-4039(00)99640-0

26. Takahashi, S.; Kuroyama, Y.; Sonogashira, K.; Hagihara, N. Synthesis 1980, 627-630. doi:10.1055/s-1980-29145

27. Seyferth, D.; Marmor, R. S.; Hilbert, P. J. Org. Chem. 1971, 36, 1379-1385. doi:10.1021/jo00809a014

28. Comins, D. L.; LaMunyon, D. H.; Chen, X. J. Org. Chem. 1997, 62, 8182-8187. doi:10.1021/jo971448u

\section{License and Terms}

This is an Open Access article under the terms of the Creative Commons Attribution License

(http://creativecommons.org/licenses/by/2.0), which permits unrestricted use, distribution, and reproduction in any medium, provided the original work is properly cited.

The license is subject to the Beilstein Journal of Organic Chemistry terms and conditions:

(http://www.beilstein-journals.org/bjoc)

The definitive version of this article is the electronic one which can be found at: doi:10.1186/1860-5397-3-29 